\title{
PENGARUH CORPORATE SOCIAL RESPONSIBILITY DAN GOOD CORPORATE GOVERNANCE TERHADAP NILAI PERUSAHAAN (STUDI PADA SEKTOR PERTAMBANGAN DI BURSA EFEK INDONESIA)
}

\author{
Budi Setyawan \\ Universitas Pamulang \\ Dosen01453@unpam.ac.id
}

\begin{abstract}
This study aims to analyze the influence of Corporate Social Responsibility and Good Corporate Governance (independent commissioner, number of directors and number of audit committees) on the value of the company in the mining issuer in Indonesia Stock Exchange. Research samples of 20 companies and years of research that is $2011-2015$. The data collected is processed by simple and multiple regression. The result of research shows that there is no influence of Corporate Social Responsibility to Corporate Value. The effect of independent commissioners on corporate value is insignificant. The effect of the number of directors on firm value is significant. The influence of audit committees on corporate value is not significant. Simultaneously CSR, independent commissioner, number of directors and number of audit committee have an effect on signifikan to Company Value. The magnitude of Corporate Social Responsibility and Good Corporate Governance (Independent Commissioner, Number of Directors and Audit Committee) to the dependent variable of Corporate Value has a coefficient of determination of 0.049 indicating that the contribution of Corporate Social Responsibility and Good Corporate Governance of Independent Commissioners, Number of Directors, and Audit Committee) together against Corporate Value is $4.9 \%$, the rest is caused by other factors.
\end{abstract}

Keywords : Corporate Social Responsibility, Good Corporate Governance, Corporate Value

\section{PENDAHULUAN}

Perusahaan dalam perkembangannya akan selalu berusaha untuk mempertahankan keunggulan bisnisnya dalam meningkatkan nilai perusahaan. Fama dan French dalam Zuraedah (2010:1) menyatakan bahwa optimalisasi perusahaan yang merupakan tujuan perusahaan dapat dicapai melalui pelaksanaan fungsi manajemen keuangan, dimana suatu keputusan keuangan yang diambil akan mempengaruhi keputusan keuangan lainnya dan berdampak pada nilai perusahaan. Nilai perusahaan dapat memberikan kemakmuran bagi pemegang saham secara maksimum apabila harga saham meningkat. Semakin tinggi harga saham perusahaan, maka semakin tinggi pula kemakmuran pemegang saham. Enterprise 
Value (EV) atau dikenal juga sebagai firm value (nilai perusahaan) merupakan konsep penting bagi investor, karena merupakan indikator bagi pasar menilai perusahaan secara keseluruhan (Nurlela dan Islahuddin, 2008:7).

Naik turunnya harga saham di pasar modal menjadi sebuah fenomena yang menarik. Turunnya harga bahan tambang yang mulai dirasakan industri tambang Indonesia sejak tahun 2012 hingga saat ini belum menunjukkan perbaikan (Sumber: CNN Indonesia, Maret 2016). Fenomena ini disebabkan oleh krisis global yang menurunkan aktivitas industri di berbagai negara sehingga eskpor komoditas tambang Indonesia yang menurun, hal itu membuat harga saham perusahaan tambang di Indonesia juga mengalami penurunan karena aksi melepas saham oleh investor yang melihat industri tambang tidak prospektif untuk mengambil untung. Kondisi tersebut dinilai mempengaruhi nilai perusahaan karena nilai perusahaan itu tercermin dari harga sahamnya.

Selain nilai perusahaan, dalam menjaga eksistensinya di dunia bisnis perusahaan tidak dapat dipisahkan dengan masyarakat sebagai lingkungan eksternalnya. Akan tetapi, perkembangan akuntansi yang lebih mementingkan kepentingan pemilik modal membuat perusahaan melakukan penggunaan sumber daya alam dan sosial secara tidak terkendali, dan mengakibatkan kerusakan lingkungan sekitar apalagi pada perusahaan pertambangan yang bersifat ekstraktif (Agustine, 2014:43). Namun seiring dengan berjalannya waktu, masyarakat semakin menyadari adanya dampak-dampak negatif yang ditimbulkan oleh perusahaan dalam menjalankan operasinya, karena itu para pelaku bisnis semakin dituntut agar tidak hanya berorientasi dalam memaksimalkan laba tetapi juga mampu memberikan kontribusi positif terhadap lingkungan sekitar dalam bentuk penyisihan dana. Bentuk kontribusi positif tersebut dapat dilakukan dengan mengembangkan apa yang disebut Corporate Social Responsibility (CSR). Kepedulian dunia usaha untuk menyisihkan dana aktifitas CSR secara berkelanjutan sebenarnya juga akan mendatangkan sejumlah manfaat bagi dunia bisnis itu sendiri, salah satunya yaitu mempertahankan dan mendongkrak reputasi serta citra merek perusahaan. Dengan begitu produk semakin disukai oleh konsumen dan perusahaan diminati oleh para investor (Handriyani, 2013:2). 
CSR sebagai konsep akuntansi yang baru adalah transparansi pengungkapan sosial atas kegiatan atau aktivitas sosial yang dilakukan oleh perusahaan, dimana transparansi informasi yang diungkapkan tidak hanya berupa informasi keuangan perusahaan saja, tetapi perusahaan juga diharapkan mengungkapkan informasi mengenai dampak-dampak sosial dan lingkungan hidup yang diakibatkan oleh aktivitas perusahaan (Handriyani, 2013:1). CSR saat ini bukan lagi bersifat sukarela (voluntary) dimana suatu perusahaan membantu mengatasi problem sosial dan lingkungan, melainkan bersikap wajib (obligation) perusahaan untuk peduli terhadap dan mengentaskan krisis kemanusiaan dan lingkungan yang terus meningkat.

Penelitian Agustine (2014) menunjukkan hasil bahwa prosentase kepemilikan manajemen dan profitabilitas sebagai variabel moderating mampu mempengaruhi hubungan CSR dengan nilai perusahaan. Secara serempak CSR, prosentase kepemilikan manajemen, profitabilitas, interaksi antara CSR dan prosentase kepemilikan manajemen, dan interaksi antara CSR dan profitabilitas berpengaruh signifikan terhadap nilai perusahaan. Pada penelitian Handriyani (2013) juga menunjukkan bahwa pengungkapan CSR mempunyai pengaruh signifikan terhadap nilai perusahaan. Demikian pula pada penelitian Yuniarta dan Sinarwati (2014) menghasilkan kesimpulan bahwa corporate social responsibility mampu memoderasi kinerja keuangan terhadap nilai perusahaan secara positif.

Selain konsep CSR, nilai perusahaan dipengaruhi oleh banyak faktor, salah satunya adalah melalui tata kelola perusahaan yang baik atau Good Corporate governance. Corporate governance merupakan suatu sistem yang mengatur dan mengendalikan perusahaan yang diharapkan dapat memberikan dan meningkatkan nilai perusahaan kepada para pemegang saham (Shleifer dan Vishny dalam Amanti, 2013:2). FCGI (Forum for Corporate governance in Indonesia) dalam Amanti (2013:2) menjelaskan bahwa tujuan dari corporate governance adalah untuk menciptakan nilai tambah bagi semua pihak yang berkepentingan (stakeholders).

Good Corporate Governance (GCG) dikatakan dapat menciptakan nilai tambah karena dengan menerapkan Good Corporate governance, diharapkan perusahaan akan memiliki kinerja yang baik sehingga dapat menciptakan nilai 
tambah dan meningkatkan nilai perusahaan yang dapat memberikan keuntungan bagi para pemegang saham atau pemilik perusahaan. Secara lebih rinci, terminologi corporate governance dapat dipergunakan untuk menjelaskan peranan dan perilaku dari dewan direksi, dewan komisaris, pengurus perusahaan, dan para pemegang saham. (Amanti, 2013:2)

Peran penting penerapan Good Corporate Governance dapat dilihat dari sisi salah satu tujuan penting dalam mendirikan sebuah perusahaan yang selain untuk meningkatkan kesejahteraan pemiliknya atau pemegang saham, juga untuk memaksimalkan kekayaan pemegang saham melalui peningkatan nilai perusahaan (Brigham dan Houston dalam Purwani 2010:47). Peningkatan nilai perusahaan tersebut dapat dicapai jika perusahaan mampu beroperasi dengan mencapai laba yang ditargetkan. Melalui laba yang diperoleh tersebut, perusahaan akan mampu memberikan deviden kepada pemegang saham, meningkatkan pertumbuhan perusahaan dan mempertahankan kelangsungan hidup perusahaan.

Penelitian Retno dan Priantinah (2012) menunjukkan GCG berpengaruh positif terhadap Nilai Perusahaan pada perusahaan yang terdaftar di BEI periode 2007-2010. Penelitian Suhartati dkk (2011) membuktikan bahwa variabel praktik GCG dan variabel kontrol telah mampu menjelaskan variabel nilai perusahaan sebesar $62,68 \%$ dan variabel GCG signifikan berpengaruh terhadap nilai perusahaan, sedangkan penelitian Amanti (2013) menunjukkan bahwa GCG memiliki efek negatif pada nilai perusahaan, hal ini dimungkinkan karena perusahaan hanya berlaku untuk memenuhi GCG formal, sehingga kepemilikan manajerial tidak memberikan nilai tambah kepada perusahaan dan keberadaan komisaris independen tidak menunjukkan perbaikan kinerja perusahaan.

Berdasarkan latar belakang yang telah diatas, maka penulis merumuskan masalah sebagai berikut :

1. Apakah Corporate Social Responsibility berpengaruh terhadap nilai perusahaan pada perusahaan sektor Pertambangan yang Terdaftar Di Bursa Efek Indonesia? 
2. Apakah Good Corporate Governance berpengaruh terhadap nilai perusahaan pada perusahaan setor Pertambangan yang Terdaftar Di Bursa Efek Indonesia ?

3. Apakah Corporate Social Responsibility dan Good Corporate Governance secara bersama-sama berpengaruh terhadap nilai perusahaan pada perusahaan sektor Pertambangan yang Terdaftar Di Bursa Efek Indonesia?

Diharapkan dari hasil penelitian ini dapat memberikan sumbangan pemikiran pada analisis, investor dan para pemegang saham serta manajemen investasi dalam menentukan keputusan strategi keuangan. Selain itu, hasil penelitian ini dapat dijadikan sebagai bahan literatur dan referensi untuk mendapatkan bahan acuan yang lebih akurat tentang penelitian yang akan dilakukan para peneliti mengenai tema yang sama.

\section{TELAAH LITERATUR DAN PENGEMBANGAN HIPOTESIS}

\section{Nilai Perusahaan}

Menurut Muliani, dkk (2014:1) nilai perusahaan adalah sebuah nilai untuk mengukur tingkat kualitas perusahaan dan sebuah nilai yang menerangkan seberapa besar tingkat kepentingan sebuah perusahaan di mata pelanggannya. Nilai perusahaan dapat mencerminkan nilai aset yang dimiliki perusahaan seperti suratsurat berharga. Saham merupakan salah satu surat berharga yang dikeluarkan oleh perusahaan, tinggi rendahnya harga saham banyak dipengaruhi oleh kondisi emiten. Salah satu faktor yang mempengaruhi harga saham adalah kemampuan perusahaan membayar dividen. Nilai perusahaan dapat dilihat dari kemampuan perusahaan membayar dividen. Pembayaran deviden dapat dijadikan tolak ukur oleh para pelanggannya dalam menilai perusahaan. Besarnya dividen ini mempengaruhi harga saham. Pembayaran deviden erat kaitannya dengan kemampuan perusahaan memperoleh laba. Apabila laba perusahaan tinggi maka dividen yang dibayar tinggi, sehingga akan mempengaruhi harga saham cenderung tinggi sehingga nilai perusahaan juga tinggi. Sebaliknya bila jika dividen yang dibayarkan kecil maka harga saham perusahaan tersebut juga rendah. 


\section{Teknik Pengukuran Nilai Perusahaan}

Pengukuran nilai perusahaan dapat dilakukan dengan menggunakan :

\section{Harga Saham}

Nilai perusahaan merupakan persepsi investor terhadap tingkat keberhasilan perusahaan yang sering dikaitkan dengan harga saham. Menurut Weston dan Brigham dalam Randy dan Juniarti (2013:305), harga saham didefinisikan sebagai: "The price at which stock sells in the market.". Sedangkan, harga pasar saham adalah nilai pasar sekuritas yang dapat diperoleh investor apabila investor menjual atau membeli saham, yang ditentukan berdasarkan harga penutupan atau closing price di bursa pada hari yang bersangkutan. Jadi, harga penutupan atau closing price merupakan harga saham terakhir kali pada saat berpindah tangan di akhir perdagangan. Harga saham yang tinggi membuat nilai perusahaan juga tinggi.

\section{Tobin's Q Ratio}

Sudiyatno dan Puspitasari (2010:13) menyatakan Tobin's Q telah digunakan khusus oleh penelitian-penelitian untuk menjelaskan sejumlah fenomena perusahaan yang beragam. Hal ini telah mensyaratkan mengenai: (a) perbedaan cross-sectional dalam pengambilan keputusan investasi dan diversifikasi (b) hubungan antara kepemilikan ekuitas manajer dan nilai perusahaan (c) hubungan antara kinerja manajer dan keuntungan penawaran tender, peluang investasi dan tanggapan penawaran tender, dan (d) pembiayaan, dividen, dan kebijakan kompensasi. Tobin's Q adalah gambaran statistik yang berfungsi sebagai proksi dari nilai perusahaan dari perspektif investor, seperti dalam defisisi yang telah dijelaskan di atas bahwa Tobin's Q merupakan nilai pasar dari firm's assets dan replacement value of those assets. Secara matematis Tobin's q dapat dihitung dengan formulasi rumus sebagai berikut :

$q=(M V S+M V D) / R V A$

Dimana: 
MVS = Market value of all

outstanding stock.

MVD = Market value of all debt .

$\mathrm{RVA}=$ Replacement value of all

production capacity.

Di dalam penggunaannya, Tobin's q mengalami modifikasi. Modifikasi Tobin's Q versi Chung dan Pruitt dalam Sudiyatno dan Puspitasari (2010:14) telah digunakan secara konsisten karena disederhanakan diberbagai simulasi permainan. Modifikasi versi ini secara statistik kira-kira mendekati Tobin's q asli dan menghasilkan perkiraan 99,6\% dari formulasi aslinya. Formulasi rumusnya sebagai berikut:

$$
\mathbf{q}=(\mathbf{M V S}+\mathbf{D}) / \mathbf{T A}
$$

Sumber : Chung dan Pruitt dalam Sudiyatno dan Puspitasari (2010:14)

Dimana:

MVS = Market value of all outstanding shares.

$\mathrm{D}=$ Debt.

TA $=$ Firm's asset's.

Menurut Chung dan Pruitt dalam Sudiyatno dan Puspitasari (2010:14) Market value of all outstanding shares (MVS) merupakan nilai pasar saham yang diperoleh dari perkalian jumlah saham yang beredar dengan harga saham (Outstanding Shares * Stock Price). Interpretasi dari skor Tobins q adalah sebagai beikut:

1) Tobin's q $<1$ Menggambarkan bahwa saham dalam kondisi undervalued. Manajemen telah gagal dalam mengelola aktiva perusahaan. Potensi pertumbuhan investasi rendah.

2) Tobin's q = 1 Menggambarkan bahwa saham dalam kondisi average. Manajemen stagnan dalam mengelola aktiva. Potensi pertumbuhan investasi tidak berkembang.

3) Tobin's $q>1$ Menggambarkan bahwa saham dalam kondisi overvalued. Manajemen berhasil dalam mengelola aktiva perusahaan. Potensi pertumbuhan investasi tinggi. 
Berdasarkan penjelasan dalam interpretasi tersebut di atas, maka investor yang akan mengejar capital gain dapat mengambil keputusan untuk membeli, menahan atau menjual saham yang dimilikinya. Tobin's q didasarkan pada pandangan bahwa nilai pasar modal merupakan nilai keseluruhan modal terpasang dan insentif yang diinvestasikan.

\section{Price to Book Value (PBV)}

Menurut Mardiyati, dkk (2012:1) nilai perusahaan dalam beberapa literatur yang dihitung berdasarkan harga saham disebut dengan beberapa istilah di antaranya Price to Book Value (PBV) yaitu perbandingan antara harga saham dengan nilai buku saham. Harga saham yang tinggi membuat nilai perusahaan juga tinggi. Nilai perusahaan yang tinggi akan diikuti oleh tingginya kemakmuran pemegang saham (Brigham dan Houston dalam Pudjiastuti (2014:31). Nilai perusahaan yang tinggi menjadi keinginan para pemilik perusahaan sebab dengan nilai perusahaan yang tinggi menunjukkan tingkat kemakmuran pemegang saham juga tinggi. Nilai perusahaan yang tinggi akan membuat pasar percaya tidak hanya pada kinerja perusahaan saat ini namun juga pada prospek perusahaan di masa depan. Pada penelitian ini nilai perusahaan akan diukur dengan menggunakan Price to Book Value (PBV) yaitu perbandingan antara harga saham dengan nilai buku saham. Berikut rumus PBV lebih rinci:

\section{PBV $=$}

Harga Saham

\section{Nilai Buku Saham}

Sumber: Pudjiastuti (2014:31)

\section{Keterangan :}

PBV : Price to Book Value

\section{Corporate Social Responsibility}

Handriyani (2013:2) menyatakan CSR sebagai konsep akuntansi yang baru adalah transparansi pengungkapan sosial atas kegiatan atau aktivitas sosial yang 
dilakukan oleh perusahaan, dimana transparansi informasi yang diungkapkan tidak hanya berupa informasi keuangan perusahaan saja, tetapi perusahaan juga diharapkan mengungkapkan informasi mengenai dampak-dampak sosial dan lingkungan hidup yang diakibatkan oleh aktivitas perusahaan. Undang-Undang Nomor 40 Tahun 2007 Pasal 74 ayat (1) tentang Perseroan Terbatas yang menyatakan perseroan yang menjalankan kegiatan usahanya di bidang dan/atau berkaitan dengan segala sumber daya alam wajib melaksanakan tanggung jawab sosial dan lingkungan.

Hadi (2011:56) menyatakan CSR merupakan sebuah gagasan dimana perusahaan tidak lagi dihadapkan pada tanggung jawab yang berpijak pada single bottom line, yaitu nilai perusahaan (corporate value) yang direfleksikan dalam kondisi keuanganya (financial) saja. Tetapi, tanggung jawab perusahaan juga harus berpijak pada triple bottom line. Konsep triple bottom line merupakan keberlanjutan dari konsep sustainable development (pembangunan berkelanjutan) yang secara explisit telah mengaitkan antara dimensi tujuan dan tanggung jawab, baik kepada shareholder (pemilik perusahaan) maupun stakeholder (publik pemangku kepentingan). Konsep tersebut menunjukkan bahwa tanggungjawab sosial perusahaan merupakan suatu bentuk tindakan yang berawal dari pertimbangan etis perusahaan yang bertujuan untuk meningkatkan ekonomi, peningkatan kualitas hidup bagi karyawan dan keluarganya, serta peningkatan kualitas hidup masyarakat sekitar dan masyarakat secara lebih luas.

Carrol (1979) dalam Cecilia, dkk (2015:3) mengemukakan konsep piramida CSR yang terdiri dari ekonomi, legal, etika dan filantropi. Arti dari piramida tersebut adalah perusahaan yang terlibat dalam CSR akan bekerja untuk membuat laba, mematuhi hukum, berperilaku etis dan menjadi perusahaan yang baik. Elkington (1997) dalam Cecilia, dkk (2015:3) mengemukakan konsep triple bottom line (people, profit, planet) yang artinya bahwa agar perusahaan dapat mempertahankan keberlangsungannya maka perlu memperhatikan 3P, yaitu tidak hanya profit, namun juga mampu memberikan kontribusi kepada masyarakat (people) serta ikut aktif dalam menjaga kelestarian lingkungan (planet) sehingga perusahaan harus seimbang dalam kegiatan sosial, ekonomi dan lingkungan. 
Muliani, dkk (2014:4) menyatakan bahwa perusahaan semakin menyadari pentingnya menerapkan program Corporate Social Responsibility (CSR) sebagai bagian dari strategi bisnisnya. Akuntabilitas dapat dipenuhi dan asimetri informasi dapat dikurangi jika perusahaan melaporkan dan mengungkapkan kegiatan CSR-nya ke para stakeholders. Dengan pelaporan dan pengungkapan CSR, para stakeholders akan dapat mengevaluasi bagaimana pelaksanaan CSR dan memberikan penghargaan/sanksi terhadap perusahaan sesuai hasil evaluasinya. Konsep pelaporan CSR digagas dalam Global Reporting Inisiative (GRI). Dalam GRI Guidelines disebutkan bahwa perusahaan harus menjelaskan dampak aktivitas perusahaan terhadap ekonomi, lingkungan dan sosial pada bagian standard disclosures. Tiga dimensi tersebut kemudian diperluas menjadi 6 dimensi, yaitu ekonomi, sosial, lingkungan, praktek tenaga kerja, hak asasi manusia, masyarakat, dan tanggungjawab produk, dimana didalamnya terdapat penjelasan sejumlah 79 item.

Wardoyo dan Veronica (2013:132) menyatakan pengungkapan sosial yang dilakukan oleh perusahaan dalam laporan tahunan dapat diukur dengan cara menghitung indeks pengungkapan sosial. Daftar pengungkapan sosial yang digunakan yaitu kemasyara $\neg$ katan, produk dan konsumen, ketenagakerjaan serta lingkungan. Diukur dengan menggunakan variabel dummy, yaitu:

Score 0 : Jika perusahaan tidak mengungkapkan item pada daftar pertanyaan.

Score 1: Jika perusahaan mengungkapkan item pada daftar pertanyaan.

Indeks pengungkapan sosial perusahaan tersebut kemudian dihitung melalui jumlah item yang sesungguhnya diungkapkan peru $\neg$ sahaan dengan jumlah semua item yang mungkin diungkapkan. Indeks pengungkapan sosial perusahaan dapat dirumuskan sebagai berikut (Wardoyo dan Veronica (2013:137) :

$$
P S=\frac{\text { Item yang diungkapkan oleh perusahaan }}{79 \mathrm{Item}} \quad \mathrm{X} \quad 100 \%
$$

Sumber : Wardoyo dan Veronica (2013:132)

Keterangan :

PS = Pengungkapan Sosial Perusahaan

79 Item $=$ Pelaporan CSR dalam GRI G3.0 Guidelines 


\section{Good Corporate Governance}

Randy dan Juniarti (2013:306) mendefinisikan corporate governance sebagai seperangkat peraturan yang mengatur hubungan antar pemegang, pengurus (pengelola) perusahaan, pihak kreditur, pemerintah, karyawan, serta pula pemegang kepentingan internal dan eksternal lainnya yang berkaitan degan hak-hak dan kewajiban mereka atau dengan kata lain suatu sistem yang mengatur dan mengendalikan perusahaan. Menurut FCGI tujuan dari GCG adalah menciptakan nilai tambah untuk stakeholder. FCGI juga berpendapat, apabila perusahaan menerapkan GCG, maka keuntungan yang bisa didapatkan oleh perusahaan antara lain perusahaan lebih mudah untuk mendapatkan tambahan modal sehingga cost of capital menjadi lebih rendah, meningkatkan kinerja bisnis, dan mempunyai dampak yang baik terhadap harga saham perusahaan.

Menurut Komite Nasional Kebijakan Governance (KNKG) yang tertuang dalam Pedoman Umum GCG Indonesia dalam Randy dan Juniarti (2013:306), terdapat 5 asas atau prinsip yang menjadi pedoman dalam penerapan GCG yaitu antara lain :

1. Transparansi (transparency), yaitu keterbukaan dalam melaksanakan proses pengambilan keputusan dan keterbukaan dalam mengemukakan informasi materiil dan relevan mengenai perusahaan. keterbukaan (transparency) maksunya keterbukaan dalam melaksanakan proses pengambilan keputusan dan keterbukaan dalam mengemukakan informasi materiil dan relevan mengenai perusahaan.

2. Kemandirian (independency), yaitu suatu keadaan di mana perusahaan dikelola secara profesional tanpa benturan kepentingan dan pengaruh/tekanan dari pihak manapun yang tidak sesuai dengan peraturan perundang-undangan yang berlaku dan prinsip-prinsip korporasi yang sehat.

3. Akuntabilitas (accountability), yaitu kejelasan fungsi, pelaksanaan dan pertanggungjawaban organ sehingga pengelolaan perusahaan terlaksana secara efektif. Akuntabilitas (accountability) dapat juga diartikan sebagai kejelasan fungsi, struktur, sistem, dan pertanggungjawaban organ perusahaan sehingga pengelolaan perusahaan terlaksana secara efektif. 
4. Pertanggungjawaban (responsibility), yaitu kesesuaian di dalam pengelolaan perusahaan terhadap peraturan perundang-undangan yang berlaku dan prinsipprinsip korporasi yang sehat. Pertanggungjawaban (responsibility) adalah kesesuaian (kepatuhan) di dalam pengelolaan perusahaan terhadap prinsip korporasi yang sehat serta peraturan yang berlaku.

5. Kewajaran (fairness), yaitu keadilan dan kesetaraan di dalam memenuhi hakhak stakeholder yang timbul berdasarkan perjanjian dan peraturan perundang-undangan yang berlaku. Kewajaran (fairness), yaitu perlakuan yang adil dan setara di dalam memenuhi hak-hak stakeholder yang timbul berdsarkan perjanjian serta peraturan perundangan yang berlaku.

Wardoyo dan Veronica (2013:132) menyatakan indikator mekanisme GCG yang digunakan adalah komisaris independen. Komisaris independen merupakan semua komisaris yang tidak memiliki kepentingan bisnis yang substansial dalam perusahaan. Independensi dewan komisaris diukur dari prosentase komisaris independen terhadap total dewan komisaris yang ada. Komisaris independen yang memiliki sekurang kurangnya 30\% dari jumlah seluruh anggota komisaris, berarti telah memenuhi pedoman GCG guna menjaga independensi, pengambilan keputusan yang efektif, tepat, dan cepat.

Wardoyo dan Veronica (2013:132) menyatakan indikator mekanisme GCG yang digunakan adalah jumlah anggota dewan direksi dalam suatu perusahaan, yang ditetapkan dalam jumlah satuan. Semakin banyak dewan komisaris maka mekanisme dalam memonitoring manajemen akan semakin baik, tentunya kepercayaan para pemegang saham juga akan semakin tinggi kepada perusahaan

Wardoyo dan Veronica (2013:132) menyatakan indikator mekanisme GCG yang digunakan adalah komite audit, komite audit diukur dengan anggota komite audit yang dimiliki suatu perusahaan. Mekanisme CG terdiri dari mekanisme internal dan mekanisme eksternal. Mekanisme internal adalah cara dalam mengendalikan perusahaan dengan menggunakan struktur dan proses internal meliputi rapat umum pemegang saham (RUPS), komposisi dewan direksi dan dewan komisaris, pertemuan board of director dan keberadaan komite audit. 


\section{Kerangka Pemikiran dan Hipotesis}

CSR saat ini bukan lagi bersifat sukarela (voluntary) dimana suatu perusahaan membantu mengatasi problem sosial dan lingkungan, melainkan bersikap wajib (obligation) perusahaan untuk peduli terhadap dan mengentaskan krisis kemanusiaan dan lingkungan yang terus meningkat. Hal ini terkait dalam UndangUndang Nomor 40 Tahun 2007 Pasal 74 ayat (1) tentang Perseroan Terbatas yang menyatakan perseroan yang menjalankan kegiatan usahanya di bidang dan/atau berkaitan dengan segala sumber daya alam wajib melaksanakan tanggung jawab sosial dan lingkungan. Sedangkan menurut Muliani, dkk (2014:1) nilai perusahaan adalah sebuah nilai untuk mengukur tingkat kualitas perusahaan dan sebuah nilai yang menerangkan seberapa besar tingkat kepentingan sebuah perusahaan di mata pelanggannya.

Penelitian Agustine (2014) menunjukkan hasil bahwa prosentase kepemilikan manajemen dan profitabilitas sebagai variabel moderating mampu mempengaruhi hubungan CSR dengan nilai perusahaan. Secara serempak CSR, prosentase kepemilikan manajemen, profitabilitas, interaksi antara CSR dan prosentase kepemilikan manajemen, dan interaksi antara CSR dan profitabilitas berpengaruh signifikan terhadap nilai perusahaan. Begitu pula penelitian Handriyani (2013) menunjukkan bahwa pengungkapan CSR mempunyai pengaruh signifikan terhadap nilai perusahaan, penelitian Yuniarta dan Sinarwati (2014) juga menghasilkan kesimpulan bahwa corporate social responcibility mampu memoderasi kinerja keuangan terhadap nilai perusahaan secara positif.

Berdasarkan teori yang telah dijabarkan, maka kerangka berpikir dalam penelitian ini adalah: 


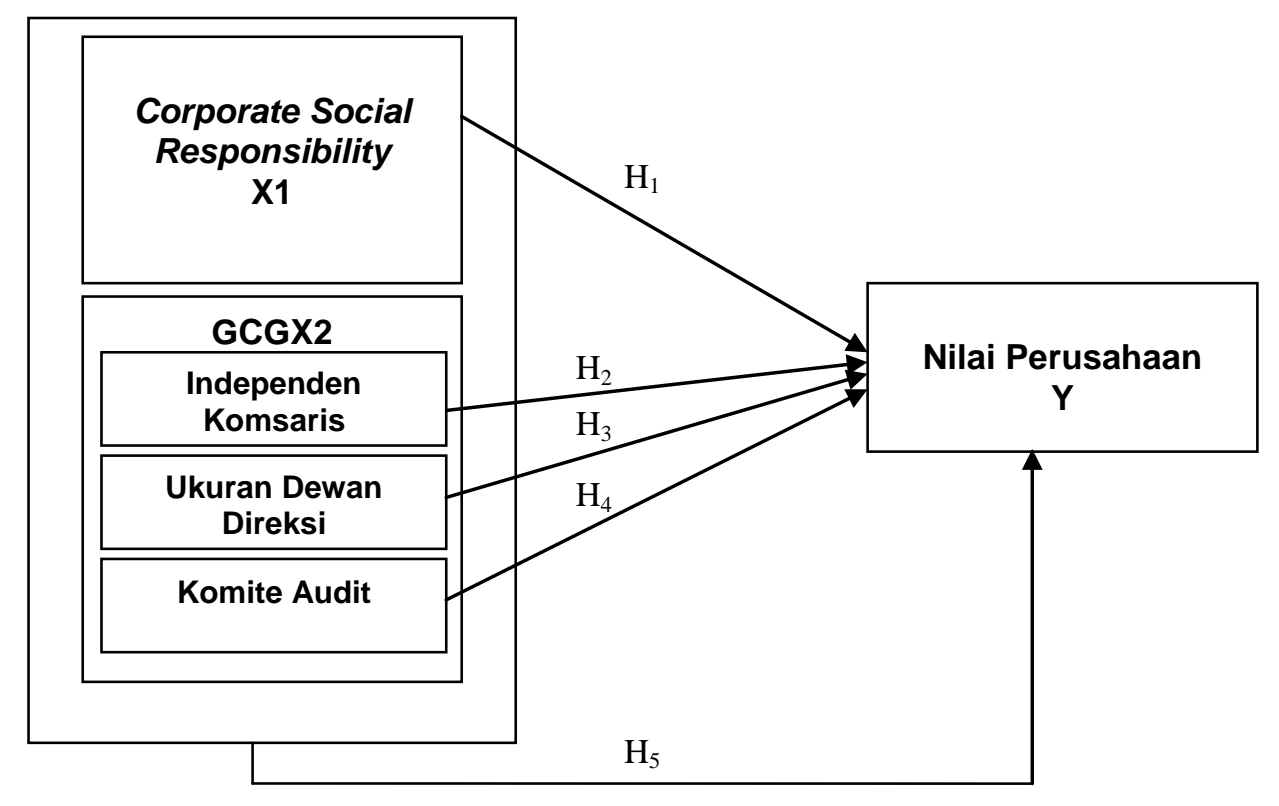

Gambar 1

Kerangka Pemikiran

Berdasarkan kerangka pemikiran diatas maka didapat suatu hipotesis sebagai berikut :

$\mathrm{H}_{1}$ Corporate Social Responsibility berpengaruh terhadap Nilai Perusahaan pada emiten sektor pertambangan di Bursa Efek Indonesia.

$\mathrm{H}_{2}$ Independen Komisaris berpengaruh terhadap Nilai Perusahaan pada emiten sektor pertambangan di Bursa Efek Indonesia.

$\mathrm{H}_{3}$ Ukuran Dewan Komisaris berpengaruh terhadap Nilai Perusahaan pada emiten sektor pertambangan di Bursa Efek Indonesia.

$\mathrm{H}_{4}$ Komite Audit berpengaruh terhadap Nilai Perusahaan pada emiten sektor pertambangan di Bursa Efek Indonesia.

$\mathrm{H}_{5}$ Corporate Social Responsibility dan Good Corporate Governance secara bersama-sama berpengaruh terhadap Nilai Perusahaan pada emiten sektor pertambangan di Bursa Efek Indonesia. 


\section{METODE PENELITIAN DAN PEMBAHASAN}

\section{Jenis Penelitian}

Penelitian ini bertujuan untuk menguji hipotesis yang telah dikemukakan di atas dengan bentuk penelitian kausal, yaitu bertujuan untuk menguji hipotesis tentang pengaruh beberapa variabel independen terhadap variabel dependen (Ghozali, 2011). Pada penelitian ini akan diuji pengaruh Corporate Social Responsibility, dan Good Corporate Governance terhadap Nilai Perusahaan pada perusahaan sector Pertambangan di Bursa Efek Indonesia.

\section{Definisi dan Operasionalisasi Variabel}

Operasional varibel diperlukan untuk menentukan jenis, indikator serta skala dari variabel-variabel yang terkait dalam penelitian, sehingga pengujian hipotesis dengan alat bantu statistik dapat dilakukan secara benar sesuai dengan judul penelitian.

\section{Nilai Perusahaan}

Nilai perusahaan adalah sebuah nilai untuk mengukur tingkat kualitas perusahaan dan sebuah nilai yang menerangkan seberapa besar tingkat kepentingan sebuah perusahaan di mata pelanggannya. Nilai perusahaan dapat mencerminkan nilai aset yang dimiliki perusahaan seperti surat-surat berharga. (Pudjiastuti, 2014:31). Nilai perusahaan dapat diukur dengan Price To Book Value (PBV), PBV adalah perbandingan antara harga saham dengan nilai buku per saham. Adapun rumus PBV adalah :

\section{PBV = Harga saham Nilai Buku saham}

\section{Corporate Social Responsibility}

Konsep akuntansi yang baru adalah transparansi pengungkapan sosial atas kegiatan atau aktivitas sosial yang dilakukan oleh perusahaan, perusahaan wajib mengungkapkan informasi mengenai dampak-dampak sosial dan lingkungan hidup yang diakibatkan oleh aktivitas perusahaan Wardoyo dan Veronica 
(2013:132). CSR dapat diukur dengan indeks pengungkapan sosial yang tercantum dalam laporan keuangan.

\section{PS = Item yang diungkapkan Perusahaan $X 100$ 79 Item}

\section{Good Corporate Governance}

Corporate Governance sebagai seperangkat peraturan yang mengatur hubungan antar stakeholders yang berkaitan dengan hak-hak dan kewajiban mereka atau dengan kata lain suatu sistem yang mengatur dan mengendalikan perusahaan (Forum for Corporate Governance in Indonesia (FCGI) dalam Wardoyo dan Veronica (2013:132). Indikator mekanisme GCG yang digunakan adalah independensi dewan komisaris, ukuran dewan direksi dan jumlah komite audit.

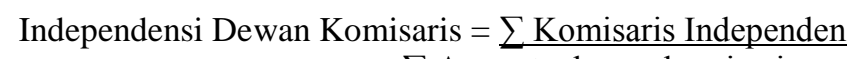

Ukuran Dewan Direksi $=\sum$ Anggota Dewan Direksi

Jumlah Komite Audit $=\sum$ Anggota Komite Audit

\section{Populasi dan Sampel}

Populasi menurut Sugiyono (2011:80) adalah wilayah generalisasi yang terdiri atas objek atau subjek yang mempunyai karakteristik tertentu yang ditetapkan oleh peneliti untuk dipelajari dan kemudian ditarik kesimpulannya. Dalam penelitian ini, populasinya adalah laporan keuangan perusahaan atau emiten pada pertambangan yang telah terdaftar di Bursa Efek Indonesia yang sebanyak 37 perusahaan.

Menurut Sugiyono (2011:95) teknik sampling dengan menggunakan metode purposive sampling adalah pengambilan sampel berdasarkan justifikasi dari peneliti berdasarkan kriteria tertentu. Adapun kriteria yang peneliti gunakan adalah:

a. Perusahaan pada sektor pertambangan dengan laporan keuangan mulai dari tahun 2011 sampai dengan tahun 2015. 
b. Memiliki catatan pengungkapan CSR lengkap.

Peneliti menggunakan sampel laporan keuangan tahun 2011-2015 karena laporan keuangan pada tahun tersebut merupakan laporan keuangan terbaru yang akan membuat analisa hasil penelitian menjadi lebih baik. Jumlah perusahaan yang menjadi sampel penelitian sebanyak 20 perusahaan.

\section{Teknik Pengumpulan Data}

Data yang digunakan peneliti dalam penelitian ini merupakan data sekunder yang diperoleh dari data-data yang sudah tersedia di Bursa Efek Indonesia. Teknik pengumpulan data merupakan cara mengumpulkan data yang dibutuhkan untuk menjawab rumusan masalah penelitian. Teknik pengumpulan data yang dilakukan oleh penulis dalam penelitian ini dilakukan dengan cara penelitian dokumen atau kepustakaan (Library Research). Studi kepustakaan yaitu teknik pengumpulan data dengan jalan mempelajari bahan-bahan bacaan yang berupa catatan-catatan keuangan perusahaan yang menjadi sampel, buku-buku, serta peraturan-peraturan yang ada kaitannya dengan masalah yang diteliti.

\section{Analisis Data dan Uji Hipotesis}

Analisis data dalam penelitian ini menggunakan regresi berganda, analisis regresi linier berganda menurut Sugiyono (2011:277) adalah analisis yang digunakan peneliti, bila bermaksud meramalkan bagaimana keadaan (naik turunnya) variabel dependen (kriterium) bila dua atau lebih variabel independen mengalami perubahan (naik turun). Rumus regresi linier berganda:

$$
\mathbf{Y}=\mathbf{a}+\mathbf{b}_{1} \mathbf{X}_{1}+\mathbf{b}_{2} \mathbf{X}_{2}+\mathbf{b}_{3} \mathbf{X}_{3}+\mathbf{b}_{4} \mathbf{X}_{4}+\mathbf{b}_{5} \mathbf{X}_{5}
$$

Keterangan :

$\begin{array}{ll}\mathrm{Y} & : \text { Nilai Perusahaan } \\ \mathrm{a} & : \text { Konstanta } \\ \mathrm{B} 1, \mathrm{~B} 2 . . \mathrm{Bn} & : \text { Koefisien regresi } \\ \mathrm{X} 1 & \text { : Indeks Pengungkapan } \\ & \text { Sosial (CSR) } \\ \mathrm{X} 2 & : \text { Independensi Dewan }\end{array}$




$\begin{array}{ll}\text { X3 } & \text { Komisaris } \\ & \text { : Ukuran Dewan } \\ & \text { Direksi } \\ \text { X4 } & \text { Jumlah Komite Audit }\end{array}$

\section{Gambaran Umum Industri Pertambangan Indonesia}

Pertambangan adalah suatu kegiatan pengambilan endapan bahan galian berharga dan bernilai ekonomis dari dalam kulit bumi, baik secara mekanis maupun manual, pada permukaan bumi, di bawah permukaan bumi dan di bawah permukaan air. Hasil kegiatan ini antara lain, minyak dan gas bumi, batubara, pasir besi, bijih timah, bijih nikel, bijih bauksit, bijih tembaga, bijih emas, perak dan bijih mangan. Penggalian adalah suatu kegiatan yang meliputi pengambilan segala jenis barang galian. Barang galian adalah unsur kimia, mineral dan segala macam batuan yang merupakan endapan alam (tidak termasuk logam, batubara, minyak dan gas bumi dan bahan radioaktif). Bahan galian ini biasanya digunakan sebagai bahan baku atau bahan penolong sektor industri maupun konstruksi. Hasil kegiatan penggalian antara lain, batu gunung, batu kali, batu kapur, koral, kerikil, batu marmer, pasir, pasir silika, pasir kuarsa, kaolin, tanah liat dan lain-lain. Kegiatan pemecahan ,peleburan, pemurnian dan segala proses pengolahan hasil pertambangan/penggalian tidak termasuk kegiatan pertambangan/penggalian, akan tetapi digolongkan ke dalam kegiatan industri.

\section{Statistik Deskriptif}

Berdasarkan rangkuman data nilai variabel Corporate Social Responsibility pada 20 emiten yang menjadi sampel penelitian. Pada tahun 2011 sampai 2015, PT Timah Tbk merupakan perusahaan yang melakukan aktivitas CSR dengan indeks CSR tertinggi dan setiap tahunnya mengalami kenaikan indeks, sedangkan selama kurun waktu 2011 sampai 2015 aktivitas CSR terendah dilakukan oleh PT Radiant Utama Interisco (RUIS) dan PT Petrosea (PTRO) dengan nilai indeks CSR sebesar 0.05 .

Berdasarkan rangkuman data Rasio Komisaris Independenpada 20 emiten yang menjadi sampel penelitian. Pada tahun 2011 sampai 2015 rasio komisaris independen tertinggi adalah PT Delta Dunia Makmur Tbk (DOID) dengan rasio 
0,67, sedangkan selama tahun 2011 sampai 2015 rasio komisaris independen terendah adalah PT Indo Tambangraya Megah (ITMG) dengan rasio 0,17.

Berdasarkan rangkuman data jumlah direksi pada 20 emiten yang menjadi sampel penelitian. Pada tahun 2011 sampai 2015 jumlah direksi tertinggi adalah PT Bayan Resources Tbk (BYAN) dengan jumlah direksi 10 orang. Sedangkan jumlah direksi terendah adalah PT SMR Utama (SMRU) dengan jumlah direksi sebanyak 2 orang saja.

Berdasarkan rangkuman data jumlah direksi pada 20 emiten yang menjadi sampel penelitian. Pada tahun 2011 dan 2014 jumlah komite audit tertinggi dengan jumlah komite audit sebanyak 4 orang cukup banyak dilakukan oleh emiten, sedangkan pada tahun 2012, 2013 dan 2015 jumlah komite audit tertinggi yakni sebanyak 5 orang adalah PT Timah Tbk (TINS). Sedangkan selama kurun waktu 2011 sampai 2015 jumlah komite audit terendah adalah PT Atlas Resources dengan jumlah jumlah komite audit sebanyak 2 orang.

Berdasarkan rangkuman data variabel nilai perusahaan pada 20 emiten yang menjadi sampel penelitian. Pada tahun 2011 nilai perusahaan tertinggi pada sektor pertambangan adalah PT Bayan Resources (BYAN) yakni sebesar 19.59 kali, sedangkan yang terendah adalah PT Radian Utama Interisco (RUIS) yakni sebesar 0.72 kali. Pada tahun 2012, nilai perusahaan tertinggi pada sektor pertambangan adalah PT Petrosea (PTRO) yakni sebesar 23.24 kali, sedangkan yang terendah adalah PT Radian Utama Interisco (RUIS) yakni sebesar 0.80 kali.

Pada tahun 2013, nilai perusahaan tertinggi pada sektor pertambangan adalah PT Vale Indonesia (INCO) yakni sebesar 11.25 kali, sedangkan yang terendah adalah PT Mitra Investindo (MITI) yakni sebesar 0.45 kali.Pada tahun 2014, nilai perusahaan tertinggi pada sektor pertambangan adalah PT Petrosea (PTRO) yakni sebesar 18.50 kali, sedangkan yang terendah adalah PT Citatah (CTTH) yakni sebesar 0.11 kali.Pada tahun 2015, nilai perusahaan tertinggi pada sektor pertambangan adalah PT Tambang Batubara Bukit Asam (PTBA) yakni sebesar 9.05 kali, sedangkan yang terendah adalah PT Mitra Investindo (RUIS) yakni sebesar 0.65 kali. 
Berdasarkan data, maka dapat dlihat bahwa nilai perusahaan pada sektor tambang pada tiap tahunnya mengalami perubahan. Sejak kurun waktu 2011-2015 perusahaan tambang yang masuk dalam kategori memiliki nilai perusahaan tinggi adalah PT Bayan Resources (BYAN), PT Petrosea (PTRO), PT Vale Indonesia (INCO) dan PT Tambang Batubara Bukit Asam (PTBA).

\section{Analisa Data}

\section{Uji Asumsi Klasik}

\section{a. Uji Normalitas}

Hasil uji normalisasi data dengan menggunakan One-Sample Kolmogorov-Smirnov Test pada SPSS 20 disajikan dalam tabel berikut:

Tabel 7

Uji Normalitas Data

\begin{tabular}{|c|c|c|c|c|c|c|}
\hline \multicolumn{7}{|c|}{ One-Sample Kolmogorov-Smirnov Test } \\
\hline & & PBV & CSR & $\begin{array}{l}\text { Komisaris } \\
\text { Independen }\end{array}$ & $\begin{array}{l}\text { Jumlah } \\
\text { Direksi }\end{array}$ & Kom_audit \\
\hline \multicolumn{2}{|l|}{$\mathrm{N}$} & 100 & 100 & 100 & 100 & 100 \\
\hline \multirow[b]{2}{*}{ Normal Parameters ${ }^{a, b}$} & Mean & ,9856 &, 1352 & $-1,0614$ & 5,0300 & 1,1551 \\
\hline & $\begin{array}{l}\text { Std. } \\
\text { Deviation }\end{array}$ & 1,00695 & ,08762 & ,33176 & 1,64197 & ,20542 \\
\hline \multirow{3}{*}{$\begin{array}{l}\text { Most Extreme } \\
\text { Differences }\end{array}$} & Absolute & ,055 & , 142 & ,263 &, 187 & ,308 \\
\hline & Positive & ,055 & ,142 &, 151 & ,187 & ,308 \\
\hline & Negative &,- 042 &,- 128 &,- 263 &,- 165 &,- 302 \\
\hline \multicolumn{2}{|l|}{ Kolmogorov-Smirnov Z } &, 551 & 1,416 & 2,634 & 1,873 & 3,084 \\
\hline \multicolumn{2}{|l|}{ Asymp. Siq. (2-tailed) } & ,922 & ,536 &, 516 & ,552 & ,589 \\
\hline
\end{tabular}

a. Test distribution is Normal.

b. Calculated from data.

Sumber : data diolah, 2017

Pada tabel di atas terlihat bahwa nilai residual yang diuji dengan KolmogorovSmirnov, semua data pada masing-masing variabel lebih besar dari 0,05 , sehingga $\mathrm{H}_{0}$ diterima, dengan kata lain bahwa data dari semua sampel pada penelitian ini berdistribusi normal. Selain itu uji normalitas dapat dilhat dari plot garis antar variabel (Normal P-P). Berikut ini hasil plot garis pada model penelitian ini dengan menggunakan SPSS versi 20.00 . 


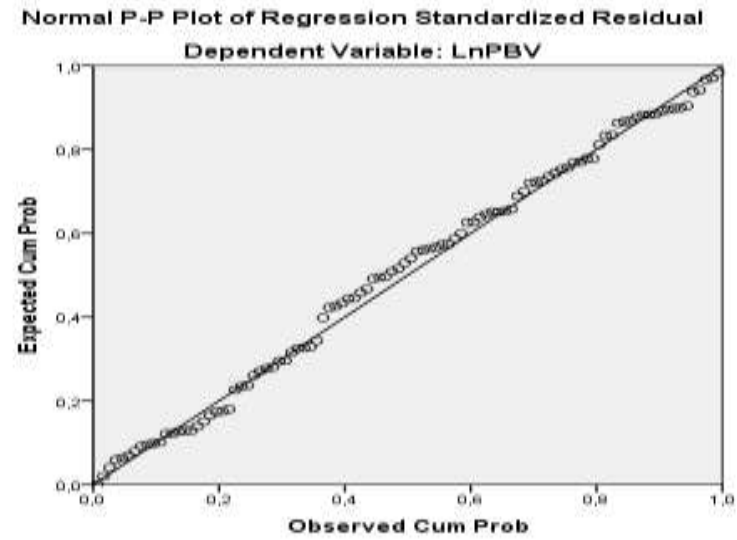

Sumber ; data diolah (2017)

\section{Gambar 2}

Plot Garis Antar Variabel (Normal P-P)

Gambar diatas adalah diagram yang menggambarkan plot antara nilai residu (ZRESID) dengan nilai prediksi (ZPRED) pada regresi jalur kedua (berganda) yang dengannya dapat terlihat normalitas sebuah model regresi berganda, pada penelitian ini, model telah normal karena nilai residu yang mengikuti alur residu normal seperti pada gambar tersebut.

\section{b. Uji Multikolinieritas}

Hasil uji multikolinieritas dilihat pada tabel berikut:

Tabel 8

Uji Multikolinieritas

Coefficients $^{\mathrm{a}}$

\begin{tabular}{|c|c|c|c|}
\hline \multirow[t]{2}{*}{ Model } & \multirow[t]{2}{*}{ Sig. } & \multicolumn{2}{|c|}{ Collinearity Statistics } \\
\hline & & Tolerance & VIF \\
\hline (Constant) & ,364 & & \\
\hline CSR & ,287 & ,938 & 1,066 \\
\hline 1 Komisaris Independen & ,447 & ,974 & 1,026 \\
\hline Jumlah Direksi & ,006 & ,987 & 1,013 \\
\hline Kom_audit & ,332 & ,955 & 1,047 \\
\hline
\end{tabular}

a. Dependent Variable: PBV

Dari tabel diatas di atas terlihat semua variabel bebas, memiliki nilai VIF $<10$ dan nilai Tolerance $>0,1$, sehingga dapat disimpulkan tidak terjadi adanya penyimpangan asumsi klasik multikolinieritas antar variabel bebas dalam model. 


\section{c. Uji Heterokedastisitas}

Uji heterokedastisitas dapat dilihat pada gambar berikut ;

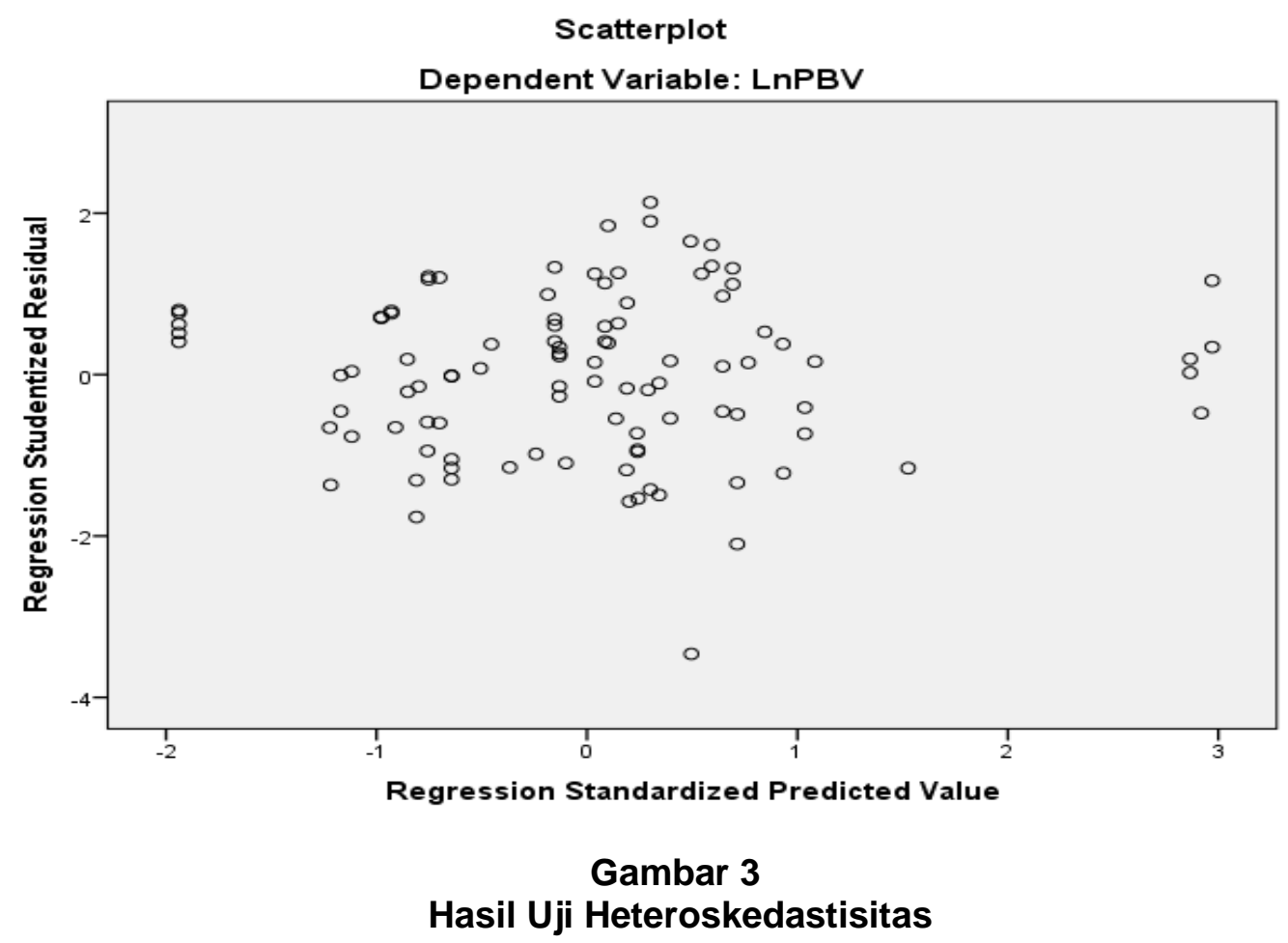

Berdasarkan Gambar diatas terlihat bahwa dengan memplotkan nilai ZPRED (nilai prediksi) dengan ZRESID (nilai residualnya). Model yang didapatkan tidak terdapat pola tertentu pada grafik, sehingga model terbebas dari masalah heterokedastisitas.

\section{d. Uji Autokorelasi}

Hasil uji autokorelasi pada penelitian ini dapat pada tabel berikut:

Tabel 9

Uji Autokorelasi

Model Summary ${ }^{\mathrm{b}}$

\begin{tabular}{|l|r|r|r|r|r|}
\hline Model & \multicolumn{1}{|c|}{$\mathrm{R}$} & $\mathrm{R}$ Square & $\begin{array}{c}\text { Adjusted R } \\
\text { Square }\end{array}$ & $\begin{array}{c}\text { Std. Error of the } \\
\text { Estimate }\end{array}$ & Durbin-Watson \\
\hline 1 &, $307^{\mathrm{a}}$ &, 094 &, 056 &, 97823 & 1,255 \\
\hline
\end{tabular}

a. Predictors: (Constant), LnKom_audit, LnKomisaris Independen, Jumlah Direksi, CSR

b. Dependent Variable: LnPBV

Dari hasil pengujian data, penelitian memiliki nilai DW $=1.255$ yang berada pada sekitar non keputusan, sehingga penelitian dapat dilanjutkan. 


\section{Regresi Berganda}

Untuk menganalisis dengan menggunakan analisis garis regresi berganda adalah dengan memperhatikan nilai yang tertera pada koefisien pada tabel berikut:

\section{Tabel 10}

Regresi Berganda

Coefficients $^{\mathrm{a}}$

\begin{tabular}{|c|c|c|c|c|c|c|}
\hline \multirow[t]{2}{*}{ Mod } & & \multicolumn{2}{|c|}{ Unstandardized Coefficients } & \multirow{2}{*}{$\begin{array}{c}\text { Standardized } \\
\text { Coefficients } \\
\text { Beta }\end{array}$} & \multirow[t]{2}{*}{$\mathrm{t}$} & \multirow[t]{2}{*}{ Sig } \\
\hline & & B & Std. Error & & & \\
\hline \multirow{5}{*}{1} & (Constant) & ,616 & 676 & & ,913 & ,364 \\
\hline & CSR & $-1,241$ & 1,159 &,- 108 & $-1,071$ & ,287 \\
\hline & Komisaris Independen &,- 229 &, 300 &,- 075 &,- 763 & ,447 \\
\hline & Jumlah Direksi & ,168 & ,060 & ,274 & 2,790 & ,006 \\
\hline & Kom_audit &,- 478 & ,490 &,- 097 &,- 976 & ,332 \\
\hline
\end{tabular}

a. Dependent Variable: Nilai Perusahaan

Sumber ; data diolah (2017)

Dari hasil olah data diperoleh persamaan regresi berganda sebagai berikut:

$$
Y=0,616-1,241 X_{1}-0,229 X_{2}+0,168 X_{3^{-}} 0,478 X_{4}
$$

Dimana :

$\mathrm{Y} \quad=$ Nilai Perusahaan

$\mathrm{X} 1=$ Corporate Social

Responsibility

X2 = Rasio Komisaris Independen

$\mathrm{X}_{3} \quad=$ Jumlah Direksi

$\mathrm{X}_{4} \quad=$ Jumlah Komite Audit

Berdasarkan persamaan regresi yang diperoleh, maka model regresi tersebut dapat diinterpretasikan sebagai berikut:

a. Koefisien konstanta sebesar 0,616 menunjukkan bahwa apabila nilai CSR, Komisaris Independen, Jumlah Direksi dan Jumlah Komite Audit bernilai nol maka tingkat Nilai Perusahaan sebesar 0,616 satuan.

b. Koefisien $b_{1}$ sebesar - 1,241 artinya apabila Corporate Social Responsibility $\left(X_{1}\right)$ mengalami kenaikan sebesar satu satuan, sementara variabel lain bersifat tetap, maka variabel Nilai Perusahaan (Y) akan menurun sebesar 1,241 satuan, jika Corporate Social Responsibility $\left(\mathrm{X}_{1}\right)$ mengalami penurunan sebesar satu satuan, sementara variabel lain bersifat tetap, maka variabel Nilai Perusahaan (Y) akan meningkat sebesar 1,241 satuan. Nilai Sig sebesar 0,287 lebih besar daripada 0,05 
$(0,287>0,05)$ sehingga disimpulkan CSR tidak berpengaruh signifikan terhadap Nilai perusahaan tambang.

c. Koefisien $b_{2}$ sebesar-0,229 artinya apabila Rasio Komisaris Independen $\left(\mathrm{X}_{2}\right)$ mengalami kenaikan sebesar satu satuan, sementara variabel lain bersifat tetap, maka variabel Nilai Perusahaan (Y) akan menurun sebesar 0,229 satuan. Jika Rasio Komisaris Independen $\left(\mathrm{X}_{2}\right)$ mengalami penurunan sebesar satu satuan, sementara variabel lain bersifat tetap, maka variabel Nilai Perusahaan (Y) akan meningkat sebesar 0,229 satuan. Nilai Sig sebesar 0,447 lebih besar daripada 0,05 $(0,447>0,05)$ sehingga disimpulkan Komisaris Independen tidak berpengaruh signifikan terhadap Nilai perusahaan tambang.

d. Koefisien $b_{3}$ sebesar 0,168 artinya apabila Jumlah Direktur $\left(X_{3}\right)$ mengalami kenaikan sebesar satu satuan, sementara variabel lain bersifat tetap, maka variabel Nilai Perusahaan (Y) akan meningkat sebesar 0,168 satuan. Jika Jumlah Direktur $\left(\mathrm{X}_{3}\right)$ mengalami penurunan sebesar satu satuan, sementara variabel lain bersifat tetap, maka variabel Nilai Perusahaan (Y) akan m sebesar 0,168 satuan. Nilai Sig sebesar 0,006 lebih kecil daripada $0,05(0,006<0,05)$ sehingga disimpulkan jumlah direktur berpengaruh signifikan terhadap Nilai perusahaan tambang.

e. Koefisien $b_{4}$ sebesar-0,478 artinya apabila jumlah komite audit $\left(\mathrm{X}_{4}\right)$ mengalami kenaikan sebesar satu satuan, sementara variabel lain bersifat tetap, maka variabel Nilai Perusahaan (Y) akanmenurun sebesar 0,478 satuan.Nilai Sig sebesar 0,332 lebih besar daripada $0,05(0,332>0,05)$ sehingga disimpulkan jumlah komite audit tidak berpengaruh signifikan terhadap Nilai perusahaan tambang.

Hipotesis persamaan regresi berganda dalam penelitian ini adalah

$\mathrm{H}_{0} \quad$ : tidak terdapat pengaruh yang signifikan Corporate Social Responsibility dan Good Corporate Governance (Komisaris Independen, Jumlah Direksi, dan Komite Audit) secara bersama-sama terhadap Nilai Perusahaan.

$\mathrm{H}_{1}$ : terdapat pengaruh yang signifikan Corporate Social Responsibility dan Good Corporate Governance (Komisaris Independen, Jumlah Direksi, dan Komite Audit) secara bersama-sama terhadap Nilai Perusahaan. 
Untuk membuktikan hipotesis tersebut adalah dengan memperhatikan nilai yang tertera pada kolom F atau kolom Sig untuk pada Tabel berikut:

Tabel 11

Koefisien Signifikansi Regresi Simultan

ANOVA $^{\mathrm{a}}$

\begin{tabular}{|rl|r|r|r|r|r|}
\hline Model & & Sum of Squares & df & Mean Square & F & Sig. \\
\hline \multirow{2}{*}{1} & Regression & 9,473 & 4 & 2,368 & 2,475 &, $049^{D}$ \\
& Residual & 90,908 & 95 &, 957 & & \\
& Total & 100,380 & 99 & & & \\
\hline
\end{tabular}

a. Dependent Variable: PBV

b. Predictors: (Constant), Kom_audit, Komisaris Independen, Jumlah Direksi, CSR Sumber ; data diolah (2017)

Dari Tabel 11.nilai $F_{\text {hitung }}=2,475>F$ hitung $=2.01$ dan Sig $=0.049<0,05$, dapat disimpulkan bahwa $\mathrm{H}_{0}$ ditolak yang berarti bahwa koefisien regresi tersebut signifikan. Dengan kata lain bahwaterdapatpengaruh yang signifkan Corporate Social Responsibility dan Good Corporate Governance (Komisaris Independen, Jumlah Direksi, dan Komite Audit) secara bersama-sama terhadap Nilai Perusahaan

\section{Koefisien Korelasi}

Koefisien korelasi pada pengujian hipotesis ini dapat dilihat pada tabel berikut:

\section{Tabel 12}

\section{Koefisien Korelasi dan Determinasi}

Model Summary

\begin{tabular}{|l|r|r|r|r|r|}
\hline Model & \multicolumn{1}{|c|}{$\mathrm{R}$} & $\mathrm{R}$ Square & $\begin{array}{c}\text { Adjusted R } \\
\text { Square }\end{array}$ & $\begin{array}{c}\text { Std. Error of the } \\
\text { Estimate }\end{array}$ & Durbin-Watson \\
\hline 1 &, $307^{\mathrm{a}}$ &, 094 &, 056 &, 97823 & 1,255 \\
\hline
\end{tabular}

a. Predictors: (Constant), Kom_audit, Komisaris Independen, Jumlah Direksi, CSR

b. Dependent Variable: PBV

Sumber ; data diolah (2017)

Koefisien korelasi (r) adalah 0,307, hal ini berarti ada hubungan yang positif antara Corporate Social Responsibility dan Good Corporate Governance (Komisaris Independen, Jumlah Direksi, dan Komite Audit) dengan Nilai Perusahaan dan hubungannya adalah rendah sebab berada pada selang korelasi 0.300 sampai 0.499 .

\section{Koefisien Determinasi}

Dari Tabel 12 Nilai R Square $=0,049$ menunjukkan bahwa besarnya kontribusi Corporate Social Responsibility danGood Corporate Governance (Komisaris Independen, Jumlah Direksi, dan Komite Audit) secara bersama-sama 
terhadap Nilai Perusahaan adalah sebesar 4,9\%, sisanya disebabkan oleh faktor lain.

Hasil penelitian didapatkan tidak terdapat pengaruh Corporate Social Responsibility terhadap Nilai Perusahaan. Penelitian ini sejalan dengan hasil penelitian Fachrur Dian dan Rika Lidyah (2014) yang menunjukkan bahwa Corporate Social Responsibility tidak berpengaruh terhadap nilai perusahaan, Penelitian Titi Suhartati, Sabar Warsini, Nedsal Sixpria (2011) juga menghasilkan kesimpulan pengungkapan CSR tidak signifikan berpengaruh terhadap nilai perusahaan. Hal ini diakibatkan karena investor di Indonesia cenderung membeli dan menjual saham tanpa memperhatikan keberlangsungan hidup perusahaan dalam jangka panjang. Investor lebih memilih saham dengan melihat market economy dan berita-berita yang muncul sehingga umumnya cenderung membeli dan menjual saham secara harian, sedangkan pengaruh CSR merupakan strategi yang tidak dapat dirasakan dalam jangka pendek, melainkan strategi jangka panjang perusahaan dalam upaya untuk menjaga keberlangsungan perusahaan. Di lain sisi, pengukuran CSR diukur dengan content analysis dengan dasar GRI Guidelines, perusahaan di Indonesia belum sepenuhnya menerapkan dan memberikan pengungkapan informasi CSR pada semua indikator secara merata. Melainkan hanya pada bidang-bidang tertentu misalnya lingkungan, sosial ataupun sumber daya manusia saja sehingga menyebabkan banyak sampel tidak memiliki indeks diatas $70 \%$.

Hasil penelitian menunjukkan tidak terdapat pengaruh Rasio Komisaris Independen terhadap Nilai Perusahaan, Hasil penelitian sesuai dengan penelitian Purwaningtyas dan Pengestuti (2011) juga menunjukkan dewan komisaris independen (DK) tidak berpengaruh terhadap nilai perusahaan. Sedangkan Carningsih (2010) yang menyatakan tidak terdapat pengaruh Rasio Komisaris Independen terhadap Nilai Perusahaan mungkin saja terjadi, karena proporsi komisaris independen dalam perusahaan yang diobservasi hanyalah bersifat formalitas untuk memenuhi regulasi saja dan tidak dimaksudkan untuk menegakkan good corporate governance (GCG) di dalam perusahaan.

Hasil penelitian menunjukkan terdapat pengaruh signifikan Jumlah Direksi terhadap Nilai Perusahaan, Hasil penelitian ini sejalan dengan hasil penelitian 
Wardoyo dan Theodora Martina Veronica (2013) yang bahwa ukuran dewan direksi memiliki pengaruh signifikan terhadap nilai perusahaan. Hal ini terjadi karena dengan besarnya ukuran dewan direksi maka semua pekerjaan dalam perusahaan dapat diselesaikan dengan detail dan fokus, sehingga meningkatkan kepercayaan publik terhadap perusahaan tersebut.

Hasil penelitian menunjukkan tidak terdapat pengaruh Jumlah Komite Audit terhadap Nilai Perusahaan, Hasil penelitian ini sejalan dengann penelitian Wardoyo, Theodora Martina Veronica (2013) yang menyatakan umlah anggota komite audit tidak memiliki pengaruh secara signifikan terhadap nilai perusahaan. Purwani (2010) menyatakan penerapan good corporate governance tidak berpengaruh secara langsung terhadap kinerja perusahaan. sedangkan Purwaningtyas dan Pengestuti (2011) juga menunjukkan komite audit (KA) menunjukkan hasil yang tidak signifikan terhadap nilai perusahaan.

\section{SIMPULAN}

Dari hasil penelitian dan analisis data, maka dapat disimpulkan sebagai berikut :

1. Hasil penelitian menunjukkan tidak terdapat pengaruh variabel bebas Corporate Social Responsibility terhadap variabel terikat Nilai Perusahaan, hal ini diakibatkan karena investor di Indonesia cenderung membeli dan menjual saham tanpa memperhatikan keberlangsungan hidup perusahaan dalam jangka panjang. Investor lebih memilih saham dengan melihat market economy dan berita-berita yang muncul sehingga umumnya cenderung membeli dan menjual saham secara harian, sedangkan pengaruh CSR merupakan strategi yang tidak dapat dirasakan dalam jangka pendek, melainkan strategi jangka panjang perusahaan dalam upaya untuk menjaga keberlangsungan perusahaan.

2. Hasil penelitian menunjukkan tidak terdapat pengaruh variabel bebas Rasio Komisaris Independen terhadap variabel terikat Nilai Perusahaan, tidak terdapat pengaruh Rasio Komisaris Independen terhadap Nilai Perusahaan mungkin saja terjadi, karena proporsi komisaris independen dalam perusahaan yang diobservasi hanyalah bersifat formalitas untuk memenuhi 
regulasi saja dan tidak dimaksudkan untuk menegakkan good corporate governance (GCG) di dalam perusahaan.

3. Hasil penelitian menunjukkan terdapat pengaruh signifikan variabel bebas Jumlah Direksi terhadap variabel terikat Nilai Perusahaan, Hal ini terjadi karena dengan besarnya ukuran dewan direksi maka semua pekerjaan dalam perusahaan dapat diselesaikan dengan detail dan fokus, sehingga meningkatkan kepercayaan publik terhadap perusahaan tersebut.

4. Hasil penelitan menunjukkan tidak terdapat pengaruh variabel bebas Jumlah Komite Audit terhadap variabel terikat Nilai Perusahaan, hal ini dimungkinkan karena perusahaan hanya berlaku untuk memenuhi GCG formal. Sehingga keberadaan komite audit tidak menunjukkan perbaikan kinerja perusahaan

5. Hasil penelitian menunjukkan CSR dan GCG berpengaruh signifikan terhadap Nilai Perusahaan. Oleh karena itu, agar dalam jangka panjang perusahaan memiliki masa depan dan keberlangsungan usaha maka program CSR dan GCG harus dilakukan perusahaan

\section{DAFTAR PUSTAKA}

Agustina, Silvia. (2013). Pengaruh Profitabilitas Dan Pengungkapan Corporate Social Responsibility Terhadap Nilai Perusahaan (Studi Empiris Pada Perusahaan Manufaktur Yang Terdaftar Di Bursa Efek Indonesia), Artikel Penelitian Program Studi Akuntansi Fakultas Ekonomi Universitas Negeri Padang.

Agustine, Ira. (2014). Pengaruh Corporate Social Responsibility Terhadap Nilai Perusahaan. Jurnal FINESTA Vol. 2, No. 1, (2014) 42-47. Program Manajemen, Program Studi Manajemen Keuangan Fakultas Ekonomi, Universitas Kristen Petra.

Ardimas, Wahyu. (2012). Pengaruh Kinerja Keuangan Dan Corporate Social Responsibility (CSR) Terhadap Nilai Perusahaan Pada Bank Go Public Yang Terdaftar Di BEI. e-Jurnal Fakultas Ekonomi, Universitas Gunadarma.

Carningsih (2010). Pengaruh Good Corporate Governance Terhadap Hubungan Antara Kinerja Keuangan Dengan Nilai Perusahaan (Studi Kasus Pada Perusahaan Property Dan Real Estate Yang Terdaftar Di Bursa Efek Indonesia), e-jurnal Universitas Gunadarma.

Cecilia Syahrul Rambem dan Zainul Bahri Torong. (2015). Analisis Pengaruh Corporate Social Responsibility, Profitabilitas dan Ukuran Perusahaan 
Terhadap Nilai Perusahaan pada Perusahaan Perkebunan yang Go Public di Indonesia, Malaysia, dan Singapura. e-jurnal Universitas Sumatera Utara.

Dian, Fachrur dan Rika Lidyah. (2014). Pengaruh Corporate Social Responsibility, Kepemilikan Manajerial dan Kepemilikan Institusi terhadap Nilai Perusahaan Tambang Batu Bara yang Terdaftar Di BEI. Jurnal STIE MDP.

Erlinda, Wahyu Dewi. (2014). Pengaruh Pengungkapan Tanggung Jawab Sosial Perusahaan Terhadap Nilai Perusahaan Dengan Kepemilikan Manajerial Sebagai Variabel Moderating (Studi Empiris Pada Perusahaan Manufaktur Yang Terdaftar Di Bursa Efek Indonesia). e-jurnal Fakultas Ekonomi dan Bisnis Universitas Dian Nuswantoro.

Handriyani, Arik Novia. (2013). Pengaruh Corporate Social Responsibility Terhadap Nilai Perusahaan Dengan Profitabilitas Sebagai Variabel Moderating. Jurnal Ilmu \& Riset Akuntansi Vol. 2 No. 5 Sekolah Tinggi Ilmu Ekonomi Indonesia (STIESIA) Surabaya.

Muliani, Luh Eni. Gede Adi Yuniarta, Kadek Sinarwati. (2014). Pengaruh Kinerja Keuangan Terhadap Nilai Perusahaan Dengan Pengungkapan Corporate Social Responcibility Dan Good Corporate Governance Sebagai Variabel Pemoderasi (Studi Kasus Di Bursa Efek Indonesia Periode 2010-2012). eJournal S1 Akuntansi Universitas Pendidikan Ganesha Jurusan Akuntansi S1 (Volume 2 No.1 Tahun 2014).

Muntiah, Siti. (2014). Pengaruh Mekanisme Corporate Governance Terhadap Kinerja Perusahaan (Studi Perusahaan Manufaktur Yang Terdaftar Di Bursa Efek Indonesia Periode 2010 - 2012). e-jurnal Universitas Dian Nuswantoro. http://eprints.dinus.ac.id/8768/1/jurnal_13448.pdf.

Muryati, Ni Nyoman Tri Sariri dan I Made Sadha Suardikha. (2014). Pengaruh Corporate Governance Pada Nilai Perusahaan. E-Jurnal Akuntansi Universitas Udayana 9.2(2014): 411-429.

Nurlela, Rika dan Islahuddin. (2010). Pengaruh Corporate Social Responsibility Terhadap Nilai Perusahaan Dengan Prosentase Kepemilikan Manajemen Sebagai Variabel Moderating (Studi Empiris Pada Perusahaan Yang Terdaftar Di Bursa Efek Jakarta). e-jurnal Universitas Syiah Kuala.

Purwani, Tri. (2010). Pengaruh Good Corporate Governance Terhadap Kinerja Perusahaan. Majalah Ilmiah Informatika Vol 1 No 2 Mei.

Purwaningtyas, Frysa Praditha dan Irene Rini Demi Pengestuti. (2011). Analisis Pengaruh Mekanisme Good Corporate Governance Terhadap Nilai Perusahaan (Studi Empiris Pada Perusahaan Manufaktur Yang Terdaftar Di BEI Tahun 20072009). e-jurnal Universitas Diponegoro. http://eprints.undip.ac.id/29375/1/JURNAL.pdf.

Randy, Vincentius dan Juniarti. (2013). Pengaruh Penerapan Good Corporate Governance Terhadap Nilai Perusahaan Yang Terdaftar Di Bei 2007-2011. Business Accounting Review, Vol. 1, No. 2, 2013.

Ratih, Suklimah. (2011). Pengaruh Good Corporate Governance Terhadap Nilai Perusahaan Dengan Kinerja Keuangan Sebagai Variabel Intervening Pada Perusahaan Peraih The Indonesia Most Trusted Company-CGPI. Jurnal Kewirausahaan Volume 5 Nomor 2, Desember 2011.

Retno M, Reny Dyah dan Denies Priantinah. (2012). Pengaruh Good Corporate Governance dan Pengungkapan Corporate Social Responsibility Terhadap 
Nilai Perusahaan (Studi Empiris Pada Perusahaan Yang Terdaftar Di Bursa Efek Indonesia Periode 2007-2010). Jurnal Nominal/Volume I Nomor I/Tahun 2012. Fakultas Ekonomi Universitas Negeri Yogyakarta.

Rosiana, Gusti Ayu Made Ervina. Gede Juliarsa dan Maria M. Ratna Sari. (2013). Pengaruh Pengungkapan CSR Terhadap Nilai Perusahaan Dengan Profitabilitas Sebagai Variabel Pemoderasi. E-Jurnal Akuntansi Universitas Udayana 5.3 (2013):723-738. ISSN: 2302-8556.

Rustiarini, Ni Wayan. (2010). Pengaruh Corporate Governancepada Hubungan Corporate Social Responsibility dan Nilai Perusahaan. Makalah Simposium Akuntansi XIII Universitas Jenderal Soedirman Purwokerto.

Sari, Enggar Fibria Verdana dan Akhmad Riduwan. (2013). Pengaruh Corporate Governance Terhadap Nilai Perusahaan: Kualitas Laba Sebagai Variabel Intervening. Jurnal Ilmu dan Riset Akuntansi Volume 1 Nomor 1, Januari 2013.

Sugiyono. (2011). Metode Penelitian Pendidikan. Alfabeta. Bandung.

Suhartati, Titi. Sabar Warsini dan Nedsal Sixpria. (2011). Pengaruh Pengungkapan Tanggung Jawab Sosial Dan Praktik Tata Kelola Perusahaan Terhadap Nilai Perusahaan. Jurnal Ekonomi Dan Bisnis, Vol 10, No. 2, Desember 2011 : 95-105.

Tumewu, Riana Christel dan Stanly W. Alexander. (2015). Pengaruh Penerapan Good Corporate Governance Terhadap Profitabilitas Pada Perusahaan Perbankan Yang Terdaftar di BEI Periode 2009-2013. Fakultas Ekonomi dan Bisnis Universitas Sam Ratulangi Manado.

Wardoyo, Theodora Martina Veronica. (2013). Pengaruh Good Corporate Governance, Corporate Social Responsibility \& Kinerja Keuangan Terhadap Nilai Perusahaan. Jurnal Dinamika Manajemen JDM Vol.4,No.2,2013,pp:132-149. 